\title{
Complete response to azacitidine priming and nab-paclitaxel in non-Hodgkin lymphoma resistant to biochemotherapy
}

\author{
RANDY C. BOWEN ${ }^{1}$, ANDREW W. HAHN ${ }^{1}$, THOMAS W. BUTLER ${ }^{2}$ and HUNG T. KHONG ${ }^{3}$ \\ ${ }^{1}$ Department of Internal Medicine, University of Utah, Salt Lake, UT 84112; ${ }^{2}$ Department of Oncology, \\ Mitchell Cancer Institute, University of South Alabama, Mobile, AL 36604; \\ ${ }^{3}$ Department of Oncology, Huntsman Cancer Institute, University of Utah, Salt Lake, UT 84112, USA
}

Received May 27, 2016; Accepted August 10, 2016

DOI: $10.3892 /$ mco.2016.1090

\begin{abstract}
The standard of care for first-line therapy in diffuse large B-cell lymphoma (DLBCL) is the rituximab, cyclophosphamide, doxorubicin, vincristine and prednisone (R-CHOP) regimen. For patients who fail to respond, have an incomplete response or relapse, numerous effective options exists besides salvage cisplatin-based regimen and autologous stem cell therapy. Even with this approach, the outcome remains very poor for this group of patients. The present case illustrates a 55-year-old woman diagnosed with DLBCL, who experienced an early incomplete response, later progression during treatment with the R-CHOP regimen. The patient received salvage therapy with rituximab, cisplatin and gemcitabine, again with an incomplete response. The patient declined consideration for stem cell therapy. Her disease progressed and she enrolled in the present phase I trial using azacitadine priming and nanoalbumin-bound (nab)-paclitaxel. After three cycles, follow-up positron emission tomography/computed tomography revealed a complete response for the first time since her initial diagnosis and the patient has remained disease-free for $>6$ years. Azacitadine and nab-paclitaxel combination appeared to be an effective regimen for the treatment of this patient with refractory DLBCL.
\end{abstract}

\section{Introduction}

Non-Hodgkin lymphoma (NHL) is the fifth most common cancer type in the USA at 7 cases per 100,000 individuals per year, and is the sixth leading cause of cancer-associated mortality in both men and women (1). Diffuse large B-cell lymphoma (DLBCL) accounts for $25 \%$ of all NHL cases and is an aggressive lymphoma with patients only having months to live

Correspondence to: Professor Hung T. Khong, Department of Oncology, Huntsman Cancer Institute, University of Utah, 2000 Circle of Hope, Salt Lake, UT 84112, USA

E-mail: hung.khong@hci.utah.edu

Key words: azacitidine, nab-paclitaxel, non-Hodgkin lymphoma, biochemotherapy without treatment (2). The first-line chemotherapy for the treatment of DLBCL is rituximab, cyclophosphamide, doxorubicin, vincristine and prednisone (R-CHOP). While improvements in first-line therapy have resulted in $67 \%$ of patients with DLBCL being in a disease-free state 4 years following diagnosis, one-third of patients with DLBCL will have disease that is refractory to initial R-CHOP ( $<50 \%$ decrease in tumor burden) or have a recurrence of their cancer after achieving complete remission (3). Due to the substantial number of patients who have refractory DLBCL, numerous second-line chemotherapy regimens have been developed for the treatment of DLBCL; however, the complete response (CR) rate for these regimens is poor, ranging between 16 and 62\% (Table I) (4-8). Additionally, a number of the second-line regimens for refractory DLBCL have significant side effect profiles (Table I); therefore, novel treatment approaches are required. The present study reported a case of refractory DLBCL treated with a novel chemotherapeutic regimen, azacitidine priming followed by nanoparticle albumin-bound (nab)-paclitaxel, that may have promise as a second-line treatment for refractory DLBCL.

\section{Case report}

A 55-year-old Caucasian female initially presented to the Mitchell Cancer Institute (Mobile, AL, USA) in September 2006 with B-symptoms of night sweats, a 40 pound weight loss and abdominal pain. Initial computed tomography (CT) of her abdomen revealed a $7 \times 7.3 \mathrm{~cm}$ size periaortic mass, multiple enlarged periaortic lymph nodes and a right upper quadrant node measuring $1.8 \times 2.6 \mathrm{~cm}$. A biopsy was performed and the patient was found to have a centroblastic variant of stage IIIB DLBCL. The patient's age adjusted International Prognostic Index (IPI) score was 3, due to an elevated lactate dehydrogenase at 307 and her stage IIIB disease. Her age adjusted IPI of 3 placed her at high risk with a $32 \%$ 5-year survival. The patient was treated with 8 cycles of R-CHOP; however, a positron emission tomography (PET)-CT at the completion of her therapy in May 2007 revealed residual disease in her mediastinum and periaortic region. The patient continued to have an excellent performance status (PS) and proceeded with 8 cycles of second-line therapy with gemcitabine, cisplatin, and rituximab. After 8 cycles, a PET-CT revealed a partial response in November 2007. The patient was evaluated for 
Table I. Summary of phase I/II clinical trials for second-line therapies in the treatment of DLBCL.

\begin{tabular}{|c|c|c|c|c|}
\hline Author, year & No. patients & Therapy & Response rate and toxicities & Refs. \\
\hline Kewalramani et al, 2004 & $\begin{array}{l}36 \text { recurrent or } \\
\text { refractory DLBCL }\end{array}$ & RICE & $\begin{array}{l}53 \% \text { CR. Grade III/IV } \\
\text { febrile neutropenia }(7.5 \%)\end{array}$ & (4) \\
\hline Mey et al, 2006 & $\begin{array}{l}53 \text { recurrent or refractory } \\
\text { aggressive B Cell NHL }\end{array}$ & DHAP+R & $\begin{array}{l}62 \% \text { RR. Grade III/IV } \\
(79 \%) \text { hematological toxicity, } \\
\text { grade III febrile neutropenia }(4 \%)\end{array}$ & (5) \\
\hline Crump et al, 2004 & $\begin{array}{l}51 \text { recurrent or refractory } \\
\text { DLBCL }\end{array}$ & GDP & $\begin{array}{l}16 \% \text { CR, } 33 \% \text { PR. Grade III/IV } \\
\text { neutropenia }(72 \%) \text {, } \\
\text { thrombocytopenia }(28 \%)\end{array}$ & (6) \\
\hline Velasquez et al, 1994 & $\begin{array}{l}122 \text { recurrent or } \\
\text { refractory adult lymphoma }\end{array}$ & ESHAP & $\begin{array}{l}37 \% \text { CR, } 27 \% \text { PR. Febrile } \\
\text { neutropenia }(30 \%) \text { and } \\
\text { treatment related mortality }(6 \%)\end{array}$ & (7) \\
\hline López et al, 2008 & $\begin{array}{l}32 \text { recurrent or refractory } \\
\text { DLBCL }\end{array}$ & GemOx & $\begin{array}{l}34 \% \mathrm{CR}, 43 \% \mathrm{RR} \text {. Grade III/IV } \\
\text { hematologic }(43 \%) \text { and } \\
\text { neurotoxicity }(7 \%)\end{array}$ & (8) \\
\hline
\end{tabular}

RR was calculated as PR+CR. RICE, rituximab, ifosfamide, carboplatin and etoposide; DHAP+R, dexamethasone, cisplatin and cytarabine, plus rituximab; GDP, gemcitabine, dexamethasone and cisplatin; ESHAP, etoposide, methylprednisolone, cytarabine and cisplatin; GemOx, gemcitabine and oxaliplatin; CR, complete remission; PR, partial remission; RR, response rate; NHL, non-Hodgkin lymphoma; DLBCL, diffuse large B-cell lymphoma.

autologous hematopoietic cell transplant (HCT), but declined this option. The patient continued rituximab alone until April 2008 when a PET-CT revealed a progressive disease.

At that time, the patient still exhibited an excellent PS of 0 and elected to enroll in a phase I clinical trial of azacitidine priming and nab-paclitaxel for the treatment of advanced or metastatic solid tumors (Clinical trial no. NCT00748553). The patient received treatment with azacitidine at $75 \mathrm{mg} / \mathrm{m}^{2}$ subcutaneously, daily from days 1 through 5 , followed by nab-paclitaxel at $100 \mathrm{mg} / \mathrm{m}^{2}$ intravenously on days 8,15 and 22, of each 28-day cycle for a total of 6 cycles. Most adverse events were grade I and II, with one grade III event (neutropenia) during cycle five. Two doses of nab-paclitaxel were withheld as a result of a grade II bronchiolitis during cycle four and the grade III neutropenia during cycle five. After cycle three, a PET-CT revealed no evidence of the disease. At $>6$ years since the patient first received study treatment, subsequent scans continued to show a $\mathrm{CR}$ with no evidence of disease recurrence. The patient experienced very few adverse events during and after treatment.

\section{Discussion}

The low CR rates observed among the numerous second-line therapies currently used for refractory DLBCL, coupled with the significant number of patients with DLBCL who are refractory to initial R-CHOP therapy, highlights the requirement for novel approaches to second-line therapy for DLBCL. Second-line therapies in refractory DLBCL are often used to attain a CR or partial remission, in order to get a patient to an autologous HCT. Second-line therapies often have significant toxicity profiles that reduce their tolerability, and when combined with their low response rates, limit the number of patients who can make it to autologous HCT (Table I). Also, numerous elderly patients and those with significant co-morbidities cannot tolerate autologous HCT (9). For these patients, a second-line therapy that can achieve a durable CR, independent of autologous HCT, with a tolerable side effect profile would be of great utility. The present study introduce a novel salvage regimen for the treatment of refractory DLBCL, azacitidine priming followed by nab-paclitaxel, that achieved a CR that has persisted for $>6$ years.

Taxanes have been tested in several trials to treat relapsed or refractory lymphomas (10-13). When used as a single agent in this patient population, paclitaxel had a response rate of $17-25 \%$ (10-12). Although, a recent pre-clinical study indicated that doxorubicin-resistant lymphoma may be particularly sensitive to taxanes (14). Nab-paclitaxel is unique in that the nanoalbumin particle activates Gp60 albumin-specific receptors on the cell walls of endothelial cells. These receptors in turn activate caveolin-1, which opens cell walls via caveolae, allowing nab-paclitaxel to enter the tumor interstitium $(15,16)$. Tumor cells release a specific protein (SPARC) that binds albumin, thus capturing nab-paclitaxel and increasing intratumoral concentrations to higher levels than observed with conventional single agent paclitaxel (17).

SPARC is a secreted glycoprotein that has been found to have a high affinity for binding albumin (18). When the promoter region of SPARC undergoes hypermethylation, it results in decreased protein expression of the SPARC. Hypermethylation of the SPARC promoter region has been noted in colorectal, pancreatic, lung and ovarian cancer types, along with decreased protein expression of the SPARC (19-22). In these cancer cells, increased expression of SPARC was accomplished through the use of a hypomethylating agent. Therefore, priming of a malignancy with a hypomethylating agent, including azacitidine, can result in increased concentrations of cytotoxic nab-paclitaxel in tumor cells. A recent pre-clinical and phase I study by Clozel et al (23), subsequent 
to the completion our phase I clinical trial, confirmed that priming with a hypomethylating agent prior to use of cytotoxic chemotherapy regimens increases the chemosensitivity of DLBCL. Clozel et al (23) demonstrated reversal of doxorubicin resistance in lymphoma cells in vitro and in vivo using DNA demethylating agents, and then performed a phase I trial using azacitidine priming prior to R-CHOP therapy for first-line treatment of newly diagnosed lymphoma patients and reported a CR in 11/12 patients.

The present study is the first, to the best of our knowledge, reported use of azacitidine priming followed by nab-paclitaxel to achieve a durable CR in refractory DLBCL. Nab-paclitaxel and azacitidine appeared to have a synergistic effect in increasing the concentration of paclitaxel in tumor cells. In the future, a clinical trial is required to further investigate the potential of nab-paclitaxel and azacitidine as a novel second-line agent for refractory DLBCL that includes the addition of an anti-CD20 agent; for example rituximab. The addition of rituximab to first and second-line therapies, particularly in those without prior exposure to rituximab, has significantly improved outcomes (24).

\section{Acknowledgements}

The abstract was presented at the American Society of Clinical Oncology (ASCO) 2011 meeting, Chicago, IL, USA and published as abstract 3095 in J Clin Oncol 29 (Suppl 1): 2011. The present study was funded by Celgene (Summit, NJ, USA).

\section{References}

1. Kohler BA, Ward E, McCarthy BJ, Schymura MJ, Ries LA, Eheman C, Jemal A, Anderson RN, Ajani UA and Edwards BK: Annual report to the nation on the status of cancer, 1975-2007, featuring tumors of the brain and other nervous system. J Natl Cancer Inst 103: 714-736, 2011.

2. Morton LM, Wang SS, Devesa SS, Hartge P, Weisenburger DD and Linet MS: Lymphoma incidence patterns by WHO subtype in the United States, 1992-2001. Blood 107: 265-276, 2006.

3. Friedberg JW: Relapsed/refractory diffuse large B-cell lymphoma. Hematology Am Soc Hematol Educ Program 2011: 498-505, 2011.

4. Kewalramani T, Zelenetz AD, Nimer SD, Portlock C, Straus D, Noy A, O'Connor O, Filippa DA, Teruya-Feldstein J, Gencarelli A, et al: Rituximab and ICE as second-line therapy before autologous stem cell transplantation for relapsed or primary refractory diffuse large B-cell lymphoma. Blood 103: 3684-3688, 2004.

5. Mey UJ, Orlopp KS, Flieger D, Strehl JW, Ho AD, Hensel M, Bopp C, Gorschlüter M, Wilhelm M, Birkmann $\mathrm{J}$, et al: Dexamethasone, high-dose cytarabine, and cisplatin in combination with rituximab as salvage treatment for patients with relapsed or refractory aggressive non-Hodgkin's lymphoma. Cancer Invest 24: 593-600, 2006.

6. Crump M, Baetz T, Couban S, Belch A, Marcellus D, Howson-Jan K, Imrie K, Myers R, Adams G, Ding K, et al: Gemcitabine, dexamethasone, and cisplatin in patients with recurrent or refractory aggressive histology B-cell non-Hodgkin lymphoma: A Phase II study by the National Cancer Institute of Canada Clinical Trials Group (NCIC-CTG). Cancer 101: 1835-1842, 2004.

7. Velasquez WS, McLaughlin P, Tucker S, Hagemeister FB, Swan F, Rodriguez MA, Romaguera J, Rubenstein E and Cabanillas F: ESHAP-an effective chemotherapy regimen in refractory and relapsing lymphoma: A 4-year follow-up study. J Clin Oncol 12: 1169-1176, 1994
8. López A, Gutiérrez A, Palacios A, Blancas I, Navarrete M, Morey M, Perelló A, Alarcón J, Martínez J and Rodríguez J: GEMOX-R regimen is a highly effective salvage regimen in patients with refractory/relapsing diffuse large-cell lymphoma: A phase II study. Eur J Haematol 80: 127-132, 2008.

9. Thieblemont $\mathrm{C}$ and Coiffier B: Lymphoma in older patients. J Clin Oncol 25: 1916-1923, 2007.

10. Press OW, LeBlanc M, O'Rourke TJ, Gagnet S, Chapman RA, Balcerzak SP and Fisher RI: Phase II trial of paclitaxel by 24-hour continuous infusion for relapsed non-Hodgkin's lymphomas: Southwest Oncology Group trial 9246. J Clin Oncol 16: 574-578, 1998.

11. Casasnovas RO, Haioun C, Dumontet C, Gabarre J, Richard B, Lederlin P, Caillot D, Stamatoullas A, Morel P, Quesnel B, et al: Phase II study of 3-hour infusion of high dose paclitaxel in refractory and relapsed aggressive non-Hodgkin's lymphomas. Groupe d'Etude des Lymphomes de l'Adulte. Haematologica 85: 502-507, 2000.

12. Kahl BS, Bailey HH, Smith EP, Turman N, Smith J, Werndli J, Williams EC, Longo WL, Kim KM, McGovern J and Jumonville A: Phase II study of weekly low-dose paclitaxel for relapsed and refractory non-Hodgkin's lymphoma: A Wisconsin Oncology Network Study. Cancer Invest 23: 13-18, 2005.

13. Westin JR, McLaughlin P, Romaguera J, Hagemeister FB, Pro B, Dang NH, Samaniego F, Rodriguez MA, Fayad L, Oki Y, et al: Paclitaxel, topotecan and rituximab: Long term outcomes of an effective salvage programme for relapsed or refractory aggressive B-cell non-Hodgkin lymphoma. Br J Haematol 167: 177-184, 2014.

14. Wu L, Wang J, Li Y, Zuo L, Zhang Z, Ouyang J, Fan J and Li H: Development of taxane-containing chemotherapy of doxorubicin-resistant diffuse large B-cell lymphoma. Anticancer Drugs 25: 826-831, 2014

15. Minshall RD, Tiruppathi C, Vogel SM and Malik AB: Vesicle formation and trafficking in endothelial cells and regulation of endothelial barrier function. Histochem Cell Biol 117: 105-112, 2002.

16. Desai N, Trieu V, Yao Z, Louie L, Ci S, Yang A, Tao C, De T, Beals B, Dykes D, et al: Increased antitumor activity, intratumor paclitaxel concentrations, and endothelial cell transport of cremophor-free, albumin-bound paclitaxel, ABI-007, compared with cremophor-based paclitaxel. Clin Cancer Res 12: 1317-1324, 2006.

17. Gupta N, Hatoum H and Dy GK: First line treatment of advanced non-small-cell lung cancer-specific focus on albumin bound paclitaxel. Int J Nanomedicine 9: 209-221, 2014.

18. Sage H, Johnson C and Bornstein P: Characterization of a novel serum albumin-binding glycoprotein secreted by endothelial cells in culture. J Biol Chem 259: 3993-4007, 1984.

19. Tai IT, Dai M, Owen DA and Chen LB: Genome-wide expression analysis of therapy-resistant tumors reveals SPARC as a novel target for cancer therapy. J Clin Invest 115: 1492-1502, 2005.

20. Sato N, Fukushima N, Maehara N, Matsubayashi H, Koopmann J, $\mathrm{Su}$ GH, Hruban RH and Goggins M: SPARC/osteonectin is a frequent target for aberrant methylation in pancreatic adenocarcinoma and a mediator of tumor-stromal interactions. Oncogene 22: 5021-5030, 2003.

21. Suzuki M, Hao C, Takahashi T, Shigematsu H, Shivapurkar N, Sathyanarayana UG, Iizasa T, Fujisawa T, Hiroshima K and Gazdar AF: Aberrant methylation of SPARC in human lung cancers. Br J Cancer 92: 942-948, 2005.

22. Mok SC, Chan WY, Wong KK, Muto MG and Berkowitz RS: SPARC, an extracellular matrix protein with tumor-suppressing activity in human ovarian epithelial cells. Oncogene 12: 1895-1901, 1996

23. Clozel T, Yang S, Elstrom RL, Tam W, Martin P, Kormaksson M, Banerjee S, Vasanthakumar A, Culjkovic B, Scott DW, et al: Mechanism-based epigenetic chemosensitization therapy of diffuse large B-cell lymphoma. Cancer Discov 3: 1002-1019, 2013.

24. Feugier P, Van Hoof A, Sebban C, Solal-Celigny P, Bouabdallah R, Fermé C, Christian B, Lepage E, Tilly H, Morschhauser F, et al: Long-term results of the $\mathrm{R}-\mathrm{CHOP}$ study in the treatment of elderly patients with diffuse large B-cell lymphoma: A study by the Groupe d'Etude des Lymphomes de l'Adulte. J Clin Oncol 23: 4117-4126, 2005. 